SAINS TANAH - Journal of Soil Science and Agroclimatology

Journal homepage: http://jurnal.uns.ac.id/tanah

\title{
Intercalation and calcination as methods to reduce expansive soil properties
}

\author{
Ristiya Adi Wiratama, Eko Hanudin*, Benito Heru Purwanto \\ Department of Soil Science, Faculty of Agriculture, Universitas Gadjah Mada, Yogyakarta, Indonesia
}

\begin{tabular}{|c|c|}
\hline ARTICLE INFO & ABSTRACT \\
\hline $\begin{array}{l}\text { Keywords: } \\
\text { Clay } \\
\text { Intercalating } \\
\text { Interlayer } \\
\text { Shrinkage } \\
\text { Swelling } \\
\text { Article history } \\
\text { Submitted: 2020-12-16 } \\
\text { Accepted: 2021-05-24 } \\
\text { Available online: 2021-06-30 } \\
\text { Published regularly: June 2021 } \\
\text { * Corresponding Author } \\
\text { Email address: } \\
\text { ekohanudin@ugm.ac.id }\end{array}$ & $\begin{array}{l}\text { The expansive ability of soil causes a series of problems in various sectors. The dominance } \\
\text { of smectite clay minerals significantly affects expansive ability because they have an } \\
\text { unstable interlayer structure. Cation intercalation and calcination is a treatment method } \\
\text { that can increase the stability of the clay interlayer structure. This research investigated } \\
\text { the effects of intercalation cations and calcination treatment on the swelling ability and } \\
\text { cracking properties in the clay from Vertisols; the cations used for intercalation were } \\
\text { aluminum and iron. The intercalation tested doses were based on the equivalent weight of } \\
0 x, 0.5 \mathrm{x} \text {, and } 1 \mathrm{x} \text { cation exchange capacity (CEC) clay value. The calcination treatments used } \\
\text { were } 200^{\circ} \mathrm{C}, 300^{\circ} \mathrm{C} \text {, and no calcination. Each treatment interaction was repeated three } \\
\text { times. Parameters observed were the total area, average crack width, average lump area, } \\
\text { total number of lumps, moisture content, swelling volume, and pH after treatment. The } \\
\text { results showed that each treatment had a significant effect. Clay with an Al intercalation } \\
\text { dose of } 1 \times \mathrm{CEC} \text { without calcination treatment had the highest total area after drying, which } \\
\text { was } 41.035 \mathrm{~cm}^{2} \text {; the lowest average crack width was } 0.153 \mathrm{~cm} \text {, and the smallest swelling } \\
\text { volume was } 3.6 \mathrm{~cm}^{3} \text {. In contrast, the clay without intercalation and calcination treatments } \\
\text { had a swelling volume up to } 10 \mathrm{~cm}^{3} \text { on the } 7^{\text {th }} \text { day. The clay with an Al intercalation dose } \\
\text { of } 1 \times \mathrm{CEC} \text { with } 200^{\circ} \mathrm{C} \text { calcination exhibited the best results in reducing the expansive clay } \\
\text { ability and can be used as a guideline for further testing to reduce the soil's expansive } \\
\text { ability. }\end{array}$ \\
\hline
\end{tabular}

How to Cite: Wiratama, R. A., Hanudin, E., \& Purwanto, B. H. (2021). Intercalation and calcination as methods to reduce expansive soil properties. Sains Tanah Journal of Soil Science and Agroclimatology, 18(1): 36-47. https://dx.doi.org/10.20961/stjssa.v18i1.46735

\section{Introduction}

Expansive properties (swelling-shrinking) of soil refer to the expansion of soil when water content is added and the shrinking and formation of cracks when water content is lost (Li \& Zhang, 2011). The expansive soil properties can cause a series of problems, such as damaging road structures and buildings, laborious tillage in agriculture, breaking roots of the plant, and triggering natural disasters. Soil is composed of three main fractions: sand, silt, and clay. Clay is the main fraction that contributes to the expansive properties of the soil. Various types of clay minerals exist in the soil, of which montmorillonite has the most significant effect on expansive soil properties (Aksu et al., 2015). One type of soil with highly expansive properties is Vertisols because it has a high montmorillonite clay content (DeCarlo \& Caylor, 2020).

Various efforts have been made to reduce the potential swelling-shrinking properties of soil. Efforts often used include the use of organic matter (Hidalgo et al., 2019) and lime (Khadka et al., 2020), building structures to retain fluctuation groundwater (Michette et al., 2017), mixing soil with sand (Sholeh, 2012), and soil compaction (Zhao et al., 2014). Most of these efforts focus on maintaining the water content so as not to experience large fluctuations or to increase the bonds between soil aggregates. It should be understood that the water content triggers the swellingshrinking properties of the soil and not the primary source of the problem. The main source of the problem in the swellingshrinking of Vertisols is the unstable interlayer structure of clay minerals.

The liming method used to reduce the swelling-shrinking properties of the soil had a mechanism through a pozzolanic reaction that binds the soil particles tighter (Cheng \& Huang, 2019). Similar to the fly ash method, the use of a synthetic polymer for stabilization (Mirzababaei et al., 2017), lignosulfonate (Alazigha et al., 2016), enzymes (Rajoria \& Kaur, 2014), or other methods with base material, such as lime or calcium and silica elements, methods have focused on 
increasing the bonds between soil particles to reduce the swelling-shrinking properties of the soil. Another mechanism used to reduce the swelling-shrinking properties of clay is to reduce the water absorption ability of the soil. One such method is soil compaction, which is often used to reduce the soil's swelling-shrinking properties by reducing soil permeability (Yuliet et al., 2011). However, the soilcompacting method carries the risk of resulting in a higher swelling-shrinking of the soil (Painuli et al., 2017). In agriculture, soil is mixed with organic matter to suppress its swelling-shrinking properties by maintaining the water content. The organic matter acts like a sponge. It coats soil particles, then helps maintain soil water content fluctuations, does not change drastically, and plays a role in binding soil particles.

There is a method to stabilize or strengthen the structure of clay by inserting cations into the interlayer space, known as the intercalation method, followed by high-temperature heating or calcination. The two processes are known as pillarization because this process aims to form an oxide pillar structure in the clay interlayer space (Mnasri-Ghnimi \& FriniSrasra, 2019). High-temperature heating causes the metal hydroxy cations (intercalant) to undergo dehydration and dehydroxylation, resulting in an oxide form that sticks to the clay interlayer space, like a supporting pillar (Lee et al., 2017; Wan et al., 2017). These pillars support the clay layers so that the size of the clay interlayer space is more stable. This pillarization method has been used in many applications, such as in medicine production until waste remediation of soil or water. The pillared clay becomes more stable in its absorptive character when attached to water. However, using the pillarization method to reduce the potential swellingshrinking properties of soil still needs further investigation, because no study has applied this method directly to the soil. Thus far, the pillarization method has been used only for clay minerals, aiming to strengthen their physical properties and adsorbent abilities. However, the pillarization method is a potential method of reducing the swelling-shrinking ability of the soil.

With this background, this research aimed to investigate the effects of the intercalation and calcination methods (pillarization method) on the swelling ability and cracking properties of clay. We expected to provide a new perspective to reduce the swelling-shrinking properties of soil by focusing more on the interlayer space of clay minerals, which causes the soil swelling-shrinking (expansive) properties, that is, by increasing the stability or strengthening the structure of the clay interlayer space. In this study, the pillarization method was tested on the clay samples extracted from Vertisols. The cations inserted (intercalated) into the interlayer space were aluminum (Al) and iron (Fe), using a dose based on the cation exchange capacity (CEC) value of the clay, combined with a high-temperature (calcination) treatment of up to $300{ }^{\circ} \mathrm{C}$. The treated clay was tested for its swelling ability in a watersaturated condition for 7 days, and then the cracks formed were measured when the clay was dried using sunlight.

\section{Material and Methods}

\subsection{Experimental variables and statistical analyses}

The clay was extracted from soil in Paseban village, Bayat District, Klaten Regency, Central Java, Indonesia, on October 19, 2019. This experiment had three independent variables: (1) the type of intercalant cation material was iron (Fe) or aluminum (Al); (2) intercalation doses based on the CEC of the clay were $0 \times$ CEC (code 0 ), $0.5 \times$ CEC (code 1), and $1 \times$ CEC (code 2 ); and (3) the calcination temperatures were $200^{\circ} \mathrm{C}$ (code $\mathrm{B}$ ), $300^{\circ} \mathrm{C}$ (code C), and without calcination (code A). Each treatment level was combined and repeated three times (numbers 1, 2, and 3 at the end of the code), but in the treatment, the intercalation of iron (Fe) and aluminum (Al) doses $0 x$ CEC was combined so that the experimental sample obtained was 45 . The experimental design is presented in Table 1.

Table 1. Experimental design

\begin{tabular}{|c|c|c|c|c|c|}
\hline \multirow[b]{2}{*}{$\begin{array}{c}\text { Type of intercalant } \\
\text { cation }\end{array}$} & \multirow[b]{2}{*}{$\begin{array}{l}\text { Intercalation } \\
\text { dose (code) }\end{array}$} & \multirow[b]{2}{*}{$\begin{array}{l}\text { Calcination temperature } \\
\text { (code) }\end{array}$} & \multicolumn{3}{|c|}{ Treatment code } \\
\hline & & & $\begin{array}{l}\text { Repetition } 1 \\
\text { (1) }\end{array}$ & $\begin{array}{c}\text { Repetition } 2 \\
(2)\end{array}$ & $\begin{array}{c}\text { Repetition } 3 \\
\text { (3) }\end{array}$ \\
\hline Iron (Fe) & $0.5 \times$ CEC (Fe1) & Without calcination (A) & Fe1A1 & Fe1A2 & Fe1A3 \\
\hline Iron (Fe) & 0.5 x CEC (Fe1) & $200^{\circ} \mathrm{C}(\mathrm{B})$ & Fe1B1 & Fe1B2 & Fe1B3 \\
\hline Iron (Fe) & 0.5 x CEC (Fe1) & $300^{\circ} \mathrm{C}(\mathrm{C})$ & Fe1C1 & $\mathrm{Fe} 1 \mathrm{C} 2$ & Fe1C3 \\
\hline Iron (Fe) & $1 \times$ CEC (Fe2) & Without calcination (A) & Fe2A1 & $\mathrm{Fe} 2 \mathrm{~A} 2$ & $\mathrm{Fe} 2 \mathrm{~A} 3$ \\
\hline Iron (Fe) & $1 \times \mathrm{CEC}(\mathrm{Fe} 2)$ & $200^{\circ} \mathrm{C}(\mathrm{B})$ & Fe2B1 & Fe2B2 & Fe2B3 \\
\hline Iron (Fe) & $1 \times$ CEC (Fe2) & $300^{\circ} \mathrm{C}(\mathrm{C})$ & $\mathrm{Fe} 2 \mathrm{C} 1$ & $\mathrm{Fe} 2 \mathrm{C} 2$ & $\mathrm{Fe} 2 \mathrm{C} 3$ \\
\hline Aluminum (Al) & $0.5 \times$ CEC (Al1) & Without calcination (A) & Al1A1 & Al1A2 & Al1A3 \\
\hline Aluminum (Al) & $0.5 \times$ CEC (Al1) & $200^{\circ} \mathrm{C}(\mathrm{B})$ & Al1B1 & Al1B2 & Al1B3 \\
\hline Aluminum (Al) & $0.5 \times$ CEC (Al1) & $300^{\circ} \mathrm{C}(\mathrm{C})$ & Al1C1 & $\mathrm{Al} 1 \mathrm{C} 2$ & Al1C3 \\
\hline Aluminum (Al) & $1 \times$ CEC (Al2) & Without calcination $(\mathrm{A})$ & Al2A1 & $\mathrm{Al} 2 \mathrm{~A} 2$ & $\mathrm{Al} 2 \mathrm{~A} 3$ \\
\hline Aluminum (Al) & $1 \times \operatorname{CEC}(\mathrm{Al} 2)$ & $200^{\circ} \mathrm{C}(\mathrm{B})$ & $\mathrm{Al} 2 \mathrm{~B} 1$ & $\mathrm{Al} 2 \mathrm{~B} 2$ & Al2B3 \\
\hline Aluminum (Al) & $1 \times \operatorname{CEC}(\mathrm{Al} 2)$ & $300^{\circ} \mathrm{C}(\mathrm{C})$ & $\mathrm{Al} 2 \mathrm{C} 1$ & $\mathrm{Al} 2 \mathrm{C} 2$ & $\mathrm{Al} 2 \mathrm{C} 3$ \\
\hline- & $0 \times \operatorname{CEC}(\mathrm{N})$ & Without calcination $(A)$ & NA1 & NA2 & NA3 \\
\hline- & $0 \times \operatorname{CEC}(\mathrm{N})$ & $200^{\circ} \mathrm{C}(\mathrm{B})$ & NB1 & NB2 & NB3 \\
\hline- & $0 \times \operatorname{CEC}(\mathrm{N})$ & $300^{\circ} \mathrm{C}(\mathrm{C})$ & NC1 & $\mathrm{NC2}$ & NC3 \\
\hline
\end{tabular}


Table 2. Initial analysis of clay extracted from soil

\begin{tabular}{|c|c|}
\hline Parameters & Value \\
\hline $\begin{array}{c}\text { CEC (percolation } \mathrm{NH}_{4}-\mathrm{Ac}, \\
\text { distillation-titration) }\end{array}$ & $44.2{\text { me } 100 \mathrm{~g}^{-1} \text { clay }}$ \\
\hline $\begin{array}{c}\text { Organic matter (Walkley-Black } \\
\text { method) }\end{array}$ & $0.952 \%$ \\
\hline $\mathrm{pH} \mathrm{H}{ }_{2} \mathrm{O}$ & 4.9 \\
\hline
\end{tabular}

Table 3. ANOVA of the swelling volume of clay ( $7^{\text {th }}$ day)

\begin{tabular}{ccccc}
\hline Source & SS & MS & $\mathrm{F}$ & Sign. \\
\hline $\mathrm{T}$ & 8.449 & 8.449 & 1432.045 & $* *$ \\
$\mathrm{D}$ & 230.838 & 115.419 & 19562.511 & $* *$ \\
$\mathrm{C}$ & 0.834 & 0.417 & 70.685 & $* *$ \\
$\mathrm{~T}^{*} \mathrm{D}$ & 6.505 & 3.252 & 551.240 & $* *$ \\
$\mathrm{~T}^{*} \mathrm{C}$ & 1.349 & 0.674 & 114.300 & $* *$ \\
$\mathrm{~T}^{*} \mathrm{D}$ C C & 53.928 & 6.741 & 1142.542 & $* *$
\end{tabular}

Remarks: $\mathrm{T}$ = type of intercalant; $\mathrm{D}=$ dose; $\mathrm{C}=$ calcination temperature; significance: ${ }^{*}=\mathrm{p}$-value $<0.05 ;{ }^{* *}=$ $\mathrm{p}$-value $<0.01 ; \mathrm{ns}=$ not significant

The variables used to assess the expansive properties of clay were the total surface area, the total number of lumps, average lump area, average crack width, moisture content after drying, the volume of clay expansion in the watersaturated condition, and $\mathrm{pH}$ of clay after treatment. Analysis of variance (ANOVA) (5\% significant level) with SPSS 21 was used in the experiments. The experimental design used was a completely randomized design. Significant treatments were further tested using the Duncan test $(p<5 \%)$.

\subsection{Preparation and clay extraction}

The soil was passed through a sieve of size $<2 \mathrm{~mm}$ and separated from any debris. Then, $10 \% \mathrm{H}_{2} \mathrm{O}_{2}$ solution was added to the soil and heated to $105^{\circ} \mathrm{C}$ several times until the foam reaction disappeared (removal of organic matter). Next, to remove carbonate material from the soil, $\mathrm{HCl}$ was added and heated to $105{ }^{\circ} \mathrm{C}$ until the foam reaction disappeared. $\mathrm{NaOH}$ was added to the soil and the mixture was dispersed in a tube container filled with distilled water. The dispersed soil was left for 24 hours; then, the part on the surface solution that was still suspended was sucked off and dried using an oven at $90{ }^{\circ} \mathrm{C}$ to obtain the clay lumps. The clay lump was sieved until its size was $<0.5 \mathrm{~mm}$. The clay samples were tested using X-ray diffraction (XRD) (with a Bruker D2 Phaser $2^{\text {nd }}$ Gen device) to confirm that the clay extracted was predominantly a type with a high swelling-shrinking ability.

\subsection{Calculation of intercalation doses}

The intercalation dose was calculated based on the CEC value of clay. Aluminum and iron intercalation doses were calculated based on the mass equivalents of $\mathrm{Al}(\mathrm{OH})_{2}{ }^{+}$and $\mathrm{Fe}(\mathrm{OH})_{2}{ }^{+}$against $0 \mathrm{x}, 0.5 \mathrm{x}$, and $1 \mathrm{x}$ the value of clay $\mathrm{CEC}$, which was then converted to the equivalent weight of $\mathrm{AlCl}_{3}$ for aluminum and $\mathrm{FeCl}_{3}$ for iron. Intercalation doses of $\mathrm{Al}$ obtained were $0 \mathrm{~g}(0 \mathrm{x}$ CEC), $1.30 \mathrm{~g}(0.5 \mathrm{x} \mathrm{CEC})$, and $2.6 \mathrm{~g}$ ( $1 \mathrm{x}$ CEC) of $\mathrm{AlCl}_{3}$ for every $20 \mathrm{~g}$ clay sample, and intercalation doses of Fe obtained were $0 \mathrm{~g}, 1.12 \mathrm{~g}$ (0.5x CEC), and $2.25 \mathrm{~g}$ (1x CEC) of $\mathrm{FeCl}_{3}$ for every $20 \mathrm{~g}$ clay sample.

\subsection{Preparation of Fe and $\mathrm{Al}$ intercalation solutions}

Intercalation solutions were made under certain $\mathrm{pH}$ conditions. According to each treatment dose, $0.4 \mathrm{M} \mathrm{NaOH}$ solution was added gradually to $0.2 \mathrm{M} \mathrm{AlCl}_{3}$ solution and stirred until the $\mathrm{pH}$ reached 3.8 . The Fe intercalation solution was prepared in the same manner as the Al intercalation solution, but $0.4 \mathrm{M} \mathrm{NaOH}$ solution was added until the $\mathrm{pH}$ reached 2.2. The intercalation solution with the desired $\mathrm{pH}$ was left for 24 hours before being applied to the clay.

\subsection{Intercalating of clays with intercalation solutions}

Each sample of clay (20 g) was suspended in $250 \mathrm{ml}$ of distilled water and left for 24 hours to widen the interlayer space. The intercalation solution was then mixed into the clay slowly, with stirring so that it was mixed evenly. The homogeneous clay suspension solution was left overnight and then dried in an oven at $75{ }^{\circ} \mathrm{C}$ to obtain clay solids. The clay was then sifted to the size $<0.5 \mathrm{~mm}$.

\subsection{High-temperature treatment (calcination)}

The fine clay $(<0.5 \mathrm{~mm})$ was heated in a muffle furnace for 6 hours. The temperatures of calcination used were $200^{\circ} \mathrm{C}$ and $300{ }^{\circ} \mathrm{C}$ with a muffle furnace, and no calcination at all. After 6 hours of calcination, the clay was left in the muffle furnace overnight.

\subsection{Clay wetting and drying treatment}

The clay wetting and drying treatments were carried out on a petri dish of size $87 \mathrm{~mm} \times 13 \mathrm{~mm}$ (Figure 5). The clay was wet using distilled water until it reached a water-saturated condition. In this experiment, $60 \mathrm{ml}$ of distilled water was poured into the petri dish and every $8 \mathrm{~g}$ clay sample was sprinkled gradually and evenly into the petri dish to perfectly wet the clay.

Table 4. Swelling volume $\left(\mathrm{cm}^{3} 2 \mathrm{~g}^{-1}\right)$ on the $7^{\text {th }}$ day

\begin{tabular}{cccc} 
Type and & \multicolumn{3}{c}{$\begin{array}{c}\text { Mean swelling volume }\left(\mathrm{cm}^{3} 2 \mathrm{~g}^{-1}\right) \text { on } \\
\text { the } 7^{\text {th }} \text { day }\end{array}$} \\
\cline { 2 - 4 } intercalant dose & \multicolumn{3}{c}{ Calcination temperature } \\
\cline { 2 - 4 } & $\begin{array}{c}\text { Without } \\
\text { calcination (A) }\end{array}$ & $200{ }^{\circ} \mathrm{C}$ & $300{ }^{\circ} \mathrm{C}$ \\
& $10.07 \mathrm{~b}$ & $10.50 \mathrm{a}$ & $7.57 \mathrm{~d}$ \\
\hline 0x CEC (N) & $4.25 \mathrm{k}$ & $4.83 \mathrm{~h}$ & $5.60 \mathrm{f}$ \\
Al 0.5x CEC (Al1) & $3.60 \mathrm{~m}$ & $3.73 \mathrm{I}$ & $4.48 \mathrm{ij}$ \\
Al 1x CEC (Al2) & $4.58 \mathrm{i}$ & $4.42 \mathrm{j}$ & $7.73 \mathrm{C}$ \\
Fe 0.5 CEC (Fe1) & $5.23 \mathrm{~g}$ & $5.62 \mathrm{f}$ & $6.03 \mathrm{e}$ \\
Fe 1x CEC (Fe2) & &
\end{tabular}

Remarks: Mean values with the same letters are not significantly different at $\alpha=0.05$

Table 5. ANOVA of the water content after drying

\begin{tabular}{ccccc}
\hline Source & SS & MS & F & Sign. \\
\hline T & 0.012 & 0.012 & 104.918 & $* *$ \\
D & 0.014 & 0.007 & 63.803 & $* *$ \\
C & 0.020 & 0.010 & 87.557 & $* *$ \\
$T^{*} \mathrm{D}$ & 0.070 & 0.035 & 310.295 & $* *$ \\
$T^{*} \mathrm{C}$ & 0.000 & 0.000 & 1.098 & $\mathrm{~ns}$ \\
$\mathrm{~T}^{*} \mathrm{D} * \mathrm{C}$ & 0.006 & 0.001 & 6.533 & $* *$ \\
\hline
\end{tabular}

Remarks: $\mathrm{T}=$ type of intercalant; $\mathrm{D}=$ dose; $\mathrm{C}=$ calcination temperature; $* *=\mathrm{p}$-value $<0.01 ; \mathrm{ns}=$ not significant 

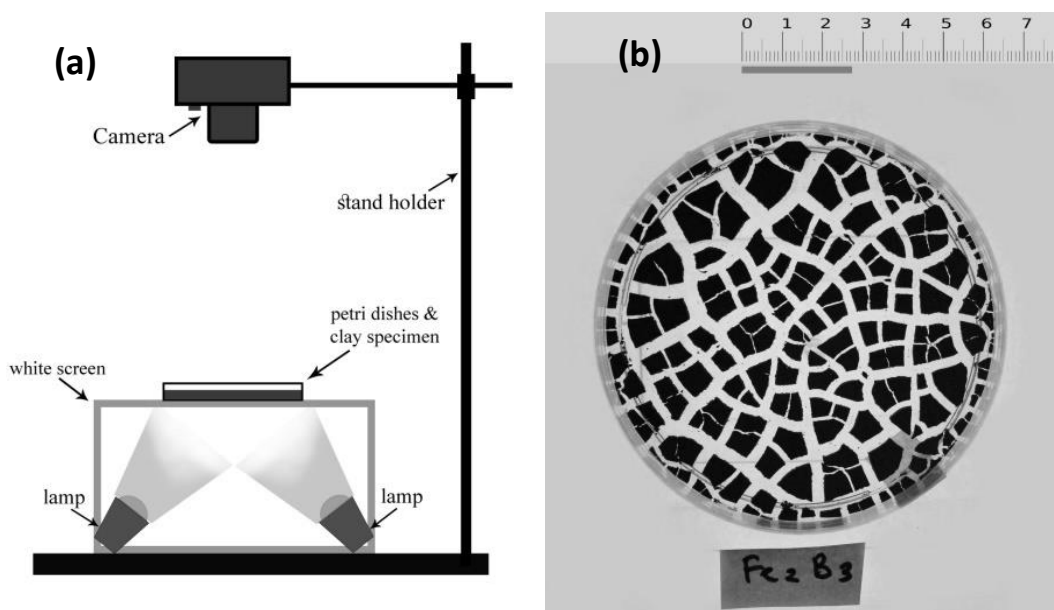

Figure 1. (a) Schematic illustration of photographing clay samples after drying and (b) an example of a clay silhouette photograph (sample Fe2B3)

The clay was left for 24 hours at room temperature to swell. The clay was left in a water-saturated condition for 24 hours to optimally absorb water before drying treatment. The swollen clay was then dried under sunlight for 7 days until its weight was constant. The dried clay sample was placed on a white screen that was highlighted by a light from below to bring up a silhouette and then photographed (Figure 1). This was done so that the boundaries of clay parts could be measured more clearly. For accuracy, ImageJ-Analysis software was used to measure the total area, total number of lumps, average lump area, and average crack width after drying. After the samples were photographed, the clay in each petri dish was weighed before and after drying in the oven $\left(105^{\circ} \mathrm{C}\right)$ to measure the water content. The average crack width after drying was calculated based on approximately 35 points distributed evenly in all parts of the clay cracks in the petri dish. The average lump area after drying was calculated based on the selection of a minimum lump area of more than $0.05 \mathrm{~cm}^{2}$. Calculated the total number of lumps after drying the same based on the selection results of the calculated average lump area after drying.

\subsection{Volume test of swollen clay}

The clay-swelling volume test was conducted in a watersaturated condition. A measuring cylinder (size $10 \mathrm{ml}$ ) was filled with $10 \mathrm{ml}$ of distilled water, and $2 \mathrm{~g}$ of clay sample was sprinkled slowly into it. Measurements were taken every 24 hours for 7 days or when the clay volume value was constant.

\section{Results}

\subsection{Initial clay analyses}

The clay used in this experiment was extracted from Vertisols that have high swelling-shrinking activity. The XRD test (Figure 2) showed that the clay consisted of predominantly montmorillonite clay, indicated by an angle of $5.9920^{\circ}$ and $d$ value of $14.73790 \AA$. As shown in Table 2, the initial clay had a CEC of 44.2 me $100 \mathrm{~g}^{-1}$ clay, and extracted clay still had an organic matter content of around $0.952 \%$.

\subsection{Volume of swollen clay}

Table 4 shows the results of the swelling volume of clay on the $7^{\text {th }}$ day. The differences in the swelling volumes of the clay samples were influenced by the calcination temperature and intercalation dose. The type of cation intercalant, calcination temperature, and intercalation dose treatment had significantly different effects on the swelling volume of clay samples (Table 3). Table 4 shows that the highest average swelling volume was found in the clay with treatment NB, which was $10.5 \mathrm{~cm}^{3}$ on the $7^{\text {th }}$ day. Meanwhile, the lowest swelling volume was found in the clay with Al2A treatment, which was $3.6 \mathrm{~cm}^{3}$ on the $7^{\text {th }}$ day. The treatment groups without intercalation (NA, NB, and NC treatments) resulted in an increased swelling volume of clay every day, in contrast to the clay group with intercalation treatment that decreased in volume every day and was constant on the $7^{\text {th }}$ day (Figure 3 ).

Table 6. Water content after drying (g)

\begin{tabular}{cccc}
\hline & \multicolumn{3}{c}{ Mean water content (g) } \\
\cline { 2 - 4 } Type and intercalant & \multicolumn{3}{c}{ Calcination temperature } \\
\cline { 2 - 4 } dose & $\begin{array}{c}\text { Without } \\
\text { calcination }\end{array}$ & $200^{\circ} \mathrm{C}(\mathrm{B})$ & $300^{\circ} \mathrm{C}$ \\
& $(\mathrm{A})$ & & (C) \\
\hline 0x CEC (N) & $1.22 \mathrm{de}$ & $1.20 \mathrm{def}$ & $1.20 \mathrm{ef}$ \\
Al 0.5x CEC (Al1) & $1.28 \mathrm{C}$ & $1.22 \mathrm{~d}$ & $1.19 \mathrm{fg}$ \\
Al 1x CEC (Al2) & $1.20 \mathrm{ef}$ & $1.17 \mathrm{gh}$ & $1.16 \mathrm{~h}$ \\
Fe 0.5 CEC (Fe1) & $1.22 \mathrm{~d}$ & $1.19 \mathrm{f}$ & $1.16 \mathrm{~h}$ \\
Fe 1x CEC (Fe2) & $1.33 \mathrm{a}$ & $1.31 \mathrm{~b}$ & $1.28 \mathrm{C}$ \\
\hline
\end{tabular}

Remark: Mean with the same letter in the same column is not significantly different at $\alpha=0.05$

Table 7. ANOVA of the total area after drying

\begin{tabular}{ccccc}
\hline Source & SS & MS & $\mathrm{F}$ & Sig. \\
\hline $\mathrm{T}$ & 5.264 & 5.264 & 147.456 & $* *$ \\
$\mathrm{D}$ & 24.580 & 12.290 & 344.264 & $* *$ \\
$\mathrm{C}$ & 23.337 & 11.668 & 326.857 & $* *$ \\
$\mathrm{~T}^{*} \mathrm{D}$ & 5.668 & 2.834 & 79.389 & $* *$ \\
$\mathrm{~T}^{*} \mathrm{C}$ & 1.350 & .675 & 18.910 & $* *$ \\
$\mathrm{~T}^{*} \mathrm{D}{ }^{*} \mathrm{C}$ & 11.236 & 1.405 & 39.344 & $* *$ \\
\hline
\end{tabular}

Remarks: $\mathrm{T}=$ type of intercalant; $\mathrm{D}=$ dose; $\mathrm{C}=$ calcination temperature; ${ }^{* *}=\mathrm{p}$-value $<0.01$ 


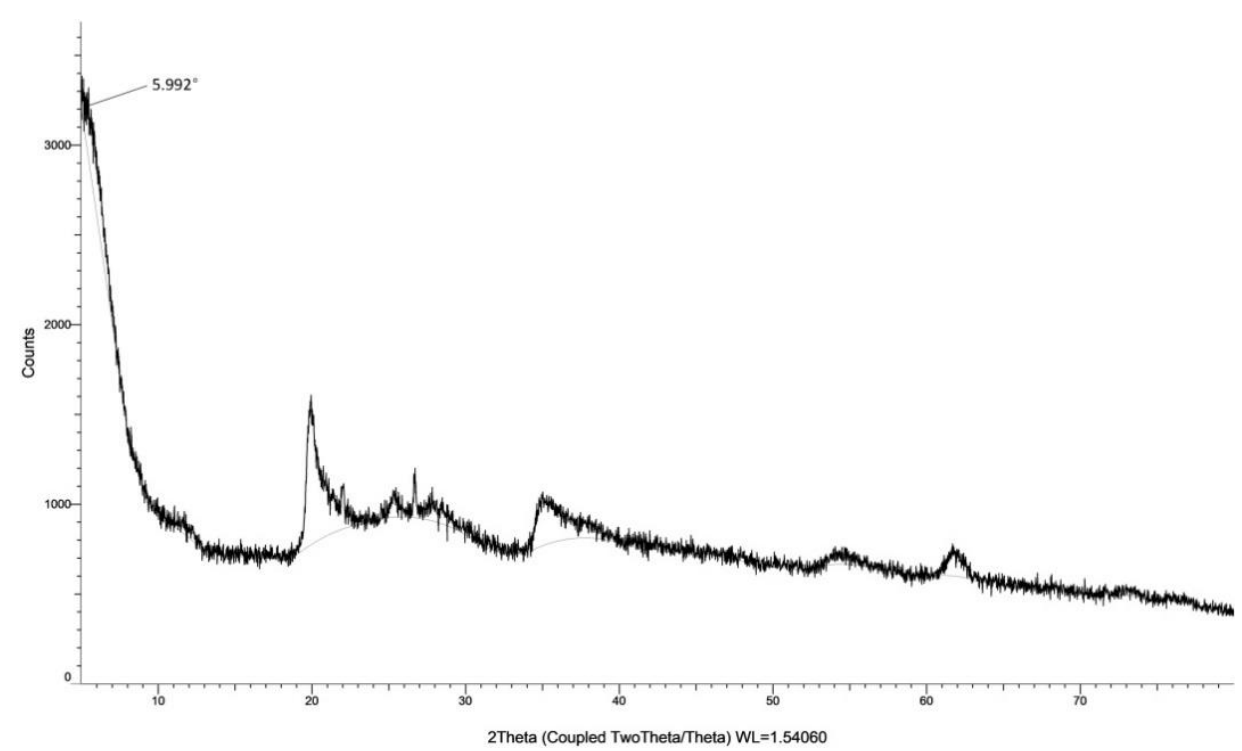

Figure 2. Diffractogram of XRD analysis of the initial clay extracted from soil

Table 8. Total area after drying $\left(\mathrm{cm}^{2}\right)$

\begin{tabular}{cccc}
\hline \multirow{2}{*}{$\begin{array}{c}\text { Type and } \\
\text { intercalant dose }\end{array}$} & \multicolumn{3}{c}{ Mean total area $\left(\mathrm{cm}^{2}\right)$} \\
\cline { 2 - 4 } & $\begin{array}{c}\text { Without } \\
\text { calcination } \\
(\mathrm{A})\end{array}$ & $200^{\circ} \mathrm{C}(\mathrm{B})$ & $300^{\circ} \mathrm{C}(\mathrm{C})$ \\
\hline 0x CEC (N) & $35.154 \mathrm{~cd}$ & $17.905 \mathrm{~h}$ & $18.153 \mathrm{~h}$ \\
Al 0.5x CEC (Al1) & $36.42 \mathrm{c}$ & $36.251 \mathrm{c}$ & $30.981 \mathrm{fg}$ \\
$\mathrm{Al} 1 \times$ CEC (Al2) & $40.718 \mathrm{a}$ & $37.716 \mathrm{~b}$ & $32.504 \mathrm{ef}$ \\
Fe 0.5 CEC (Fe1) & $34.956 \mathrm{~cd}$ & $33.983 \mathrm{de}$ & $29.102 \mathrm{~g}$ \\
Fe 1x CEC (Fe2) & $31.071 \mathrm{fg}$ & $30.528 \mathrm{fg}$ & $29.803 \mathrm{~g}$ \\
\hline
\end{tabular}

Remark: Mean with the same letter in the same column is not significantly different at $\alpha=0.05$

Table 9. ANOVA of the total number of lumps after drying

\begin{tabular}{ccccc}
\hline Source & SS & MS & $\mathrm{F}$ & Sign. \\
\hline $\mathrm{T}$ & 14.363 & 14.363 & 86.080 & $* *$ \\
$\mathrm{D}$ & 802.273 & 401.137 & 2404.014 & $* *$ \\
$\mathrm{C}$ & 2.693 & 1.346 & 8.070 & $* *$ \\
$\mathrm{~T}^{*} \mathrm{D}$ & 8.790 & 4.395 & 26.340 & $* *$ \\
$\mathrm{~T}^{*} \mathrm{C}$ & 40.223 & 20.111 & 120.528 & $* *$ \\
$\mathrm{~T}^{*} \mathrm{D}$ C C & 132.578 & 16.572 & 99.318 & $* *$ \\
\hline
\end{tabular}

Remarks: $T$ = type of intercalant; $D=$ doses; $C=$ calcination temperature; $* *=p$-value $<0.01$

\subsection{Water content after drying}

The whole treatment had significantly different effects on the swelling volume of clay samples, except in the interaction type of Intercalant treatment and calcination temperature treatment was not significant (Table 5). Table 6 describes the water content remaining in the clay samples after drying. Table 6 shows that a higher calcination temperature decreased the water content of clay after drying, such as in the $\mathrm{Al} 2 \mathrm{C}$ treatment: the water content was lower than $\mathrm{Al} 2 \mathrm{~A}$ or $\mathrm{Al} 2 \mathrm{~B}$, and that of $\mathrm{Al} 1 \mathrm{C}$ treatment was lower than of $\mathrm{Al} 1 \mathrm{~A}$ or Al1B treatment. The clay sample with the Fe2A treatment had the highest water content after drying, which was $1.33 \mathrm{~g}$. The higher intercalation dose in the Fe intercalant caused the water content after drying to be higher, in contrast to the $\mathrm{Al}$ intercalant treatment, which caused the water content to decrease.

\subsection{Total area after drying}

The type of cation intercalant, calcination temperature, and intercalation dose treatment had significantly different effects on the total area after drying (Table 7). The measurement of the total area of clay after drying is presented in Table 8. The type of intercalant cation, intercalation dose, and calcination temperature, as well as the interaction between each treatment and clay sample, had significant effects on the total area after drying. Table 8 shows that the clay with AI2A treatment had the highest total area of $40.7 \mathrm{~cm}^{2}$. Clay samples without intercalation treatment (NA, NB, and NC groups) had the smallest total area. The higher calcination temperature treatments caused the total area after drying to decrease.

\subsection{Total number of lumps after drying}

The type of cation intercalant, calcination temperature, and intercalation dose treatment had significantly different effects on the total number of lumps after drying (Table 9). Table 10 shows that clay samples without intercalation treatment had the smallest total number of lumps compared with samples with intercalation treatment; the NA, NB, and NC treatment groups had 2, 1, and 3 lumps, respectively. Table 10 shows that intercalation treatment increased the total number of lumps in clay after drying.

Table 10. Total number of lumps after drying

\begin{tabular}{|c|c|c|c|}
\hline \multirow{3}{*}{$\begin{array}{l}\text { Type and } \\
\text { intercalant dose }\end{array}$} & \multicolumn{3}{|c|}{ Mean total number of lumps } \\
\hline & \multicolumn{3}{|c|}{ Calcination temperature } \\
\hline & $\begin{array}{c}\text { Without } \\
\text { calcination }(A)\end{array}$ & $\begin{array}{c}200^{\circ} \mathrm{C} \\
\text { (B) }\end{array}$ & $\begin{array}{c}300^{\circ} \mathrm{C} \\
\text { (C) }\end{array}$ \\
\hline $0 \times \operatorname{CEC}(\mathrm{N})$ & $2 \mathrm{j}$ & $1 \mathrm{j}$ & $33 \mathrm{i}$ \\
\hline Al 0.5x CEC (Al1) & $205 c$ & 226 b & 195 de \\
\hline Al 1x CEC (Al2) & $155 \mathrm{~g}$ & $182 \mathrm{f}$ & $244 \mathrm{a}$ \\
\hline Fe 0.5 CEC (Fe1) & $220 \mathrm{~b}$ & 191 def & $113 \mathrm{~h}$ \\
\hline Fe $1 \times$ CEC (Fe2) & 188 def & 184 ef & $196 \mathrm{~cd}$ \\
\hline
\end{tabular}

Remark: Mean with the same letter in the same column is not significantly different at $\alpha=0.05$ 
The clay with $\mathrm{Al} 2 \mathrm{C}$ treatment had the highest total number of lumps after drying, which were 244 lumps. The smallest number of lumps after drying was in clay with NB treatment, which was just 1 lump.

\subsection{Average lump area after drying}

The type of cation intercalant, calcination temperature, and intercalation dose treatment had significantly different effects on the average lump area after drying (Table 11). Table 12 shows that NA treatment resulted in the highest average lump area after drying, but this was not significantly different with the NB and NC treatments. Clay with NA treatment had the largest average lump area after drying because, with this treatment, the clay consolidated into one lump, of area $35.154 \mathrm{~cm}^{2}$. There was a high correlation between the resulting total number of lumps (Table 10) and the average lump area (Table 12). Clay with $\mathrm{Al} 2 \mathrm{C}$ treatment had the highest total number of lumps and the smallest average lump area after drying, which was $0.188 \mathrm{~cm}^{2}$.

\subsection{Average crack width after drying}

Table 14 shows the results of the crack width of clay samples after drying. The type of intercalant cation, intercalation dose, and calcination temperature treatments had significant effects on the average crack width in clay after drying (Table 13). The interaction among treatments had a significant effect on each other, except for the interaction between the type of intercalant cation and calcination temperature. The $\mathrm{Al} 2 \mathrm{~A}$ and $\mathrm{Al} 2 \mathrm{~B}$ treatments had the smallest crack widths of all other treatments, but the widths were not significantly different with Al1A, Al1B, Al2C, or Fe1A treatments. Clay with $\mathrm{Al} 2 \mathrm{~A}$ and $\mathrm{Al} 2 \mathrm{~B}$ treatments had the smallest crack widths after drying, which were $0.156 \mathrm{~cm}$ and $0.158 \mathrm{~cm}$, respectively. The largest crack width after drying was in clay with NB treatment, which was $2.038 \mathrm{~cm}$. The clay without intercalation and calcination treatment (NA treatment) had a crack width of $0.935 \mathrm{~cm}$.

\section{8. $\mathrm{pH}$ of clay after treatment}

The type of cation intercalant, calcination temperature, and intercalation dose treatment had significantly different effects on the $\mathrm{pH}$ of clay after treatment (Table 15). Table 16 shows the $\mathrm{pH}$ of clay after intercalation and calcination treatment. A pH test was conducted to check the effectiveness of calcination and intercalation treatments on the clay samples. The $\mathrm{pH}$ of the initial clay was 4.77 (Table 16). Table 16 shows that a higher calcination temperature caused the $\mathrm{pH}$ of clay with an intercalation treatment to increase, in contrast to clay without intercalation treatment (NA, NB, and $\mathrm{NC}$ ). Clay without intercalation treatment (NA, NB, and NC) experienced a decrease in $\mathrm{pH}$ value when the calcination temperature was increased. The clay with Al intercalation experienced a more drastic increase in $\mathrm{pH}$ value than that with Fe intercalation when the calcination temperature was increased for each treatment.

\section{Discussion}

\subsection{Swelling volume and water content of clay after drying}

Based on various analytical parameters in this study, the intercalation and calcination methods suppressed the expansive ability of clay, especially in the clay treated with an Al intercalation dose $1 \times$ CEC and calcination temperature 200 ${ }^{\circ} \mathrm{C}$. The clay with the Al intercalation dose $1 \mathrm{x}$ CEC without calcination indeed had the smallest swelling volume (Table 4), the largest total area after drying (Table 8), and the smallest average crack width (Table 14) compared with other treatments. However, with this treatment, the Al cations had not yet turned into an oxide pillar in the interlayer space because they had not received the heat treatment (calcination). The intercalation method in clay would be less effective in stabilizing the interlayer space if not followed by calcination treatment. The intercalant molecules that do not receive calcination will not change into an interlayer space stabilizer structure because the form of the molecules can still change. The change of this intercalant molecular form is due to the influence of environmental pH (soil). Each intercalant molecule formed previously at a certain $\mathrm{pH}$ aims to make the form of intercalant molecules fit and attach to the clay interlayer space properly. Based on data presented in Figure 4 , intercalant Fe is made at a $\mathrm{pH}$ of around 2.2 to make it more dominant in the form of $\mathrm{Fe}(\mathrm{OH})^{2+}$, and intercalant $\mathrm{Al}$ is made at a $\mathrm{pH}$ of around 3.8 to make it more dominant in the form of $\mathrm{Al}(\mathrm{OH})^{2+}$. The two positive charges of these intercalant molecules will bind to the negative charges of two different clay layers. Intercalant molecules that have been successfully inserted and attached to the clay interlayer space can gradually change their molecular form without calcination treatment as they are affected by the $\mathrm{pH}$ of the initial clay (Table 2), and then change into the dominant intercalant molecule form. Therefore, calcination treatment is required for the intercalant cations to change immediately into an oxide pillar, because without calcination, the number of intercalant cation molecules in the interlayer space decreased easily (Chang et al., 2019).

Table 11. ANOVA of average lump area after drying

\begin{tabular}{ccccc}
\hline Source & SS & MS & $\mathrm{F}$ & Sig. \\
\hline $\mathrm{T}$ & 275.313 & 275.313 & 4.265 & $*$ \\
$\mathrm{D}$ & 59829.171 & 29914.585 & 463.383 & $* *$ \\
$\mathrm{C}$ & 5100.942 & 2550.471 & 39.507 & $* *$ \\
$\mathrm{~T}^{*} \mathrm{D}$ & 3143.803 & 1571.901 & 24.349 & $* *$ \\
$\mathrm{~T}^{*} \mathrm{C}$ & 6843.954 & 3421.977 & 53.007 & $* *$ \\
$\mathrm{~T}^{*} \mathrm{D}^{*} \mathrm{C}$ & 24064.927 & 3008.116 & 46.596 & $* *$
\end{tabular}

Remarks: $\mathrm{T}=$ type of intercalant; $\mathrm{D}=$ dose; $\mathrm{C}=$ calcination temperature; ${ }^{*}=p$-value $<0.05 ;{ }^{*}=p$-value $<0.01$

Table 12. Average lump area after drying $\left(\mathrm{cm}^{2}\right)$

\begin{tabular}{cccc}
\hline \multirow{2}{*}{$\begin{array}{c}\text { Type and } \\
\text { intercalant dose }\end{array}$} & \multicolumn{3}{c}{ Mean average lump area $\left(\mathrm{cm}^{2}\right)$} \\
\cline { 2 - 4 } & $\begin{array}{c}\text { Calcination temperature } \\
\text { calcination }(\mathrm{A})\end{array}$ & $200^{\circ} \mathrm{C}(\mathrm{B})$ & $\begin{array}{c}300^{\circ} \mathrm{C} \\
\text { (C) }\end{array}$ \\
\hline 0x CEC (N) & $35.154 \mathrm{a}$ & $13.526 \mathrm{a}$ & $1.226 \mathrm{a}$ \\
Al 0.5x CEC (Al1) & $0.253 \mathrm{~d}$ & $0.222 \mathrm{f}$ & $0.234 \mathrm{e}$ \\
$\mathrm{Al} 1 \times \mathrm{CEC}(\mathrm{Al} 2)$ & $0.406 \mathrm{~b}$ & $0.291 \mathrm{c}$ & $0.188 \mathrm{~g}$ \\
Fe 0.5 CEC (Fe1) & $0.250 \mathrm{de}$ & $0.248 \mathrm{de}$ & $0.332 \mathrm{~b}$ \\
Fe 1x CEC (Fe2) & $0.243 \mathrm{de}$ & $0.236 \mathrm{e}$ & $0.219 \mathrm{f}$ \\
\hline
\end{tabular}

Remark: Mean with the same letter in the same column is not significantly different at $\alpha=0.05$ 


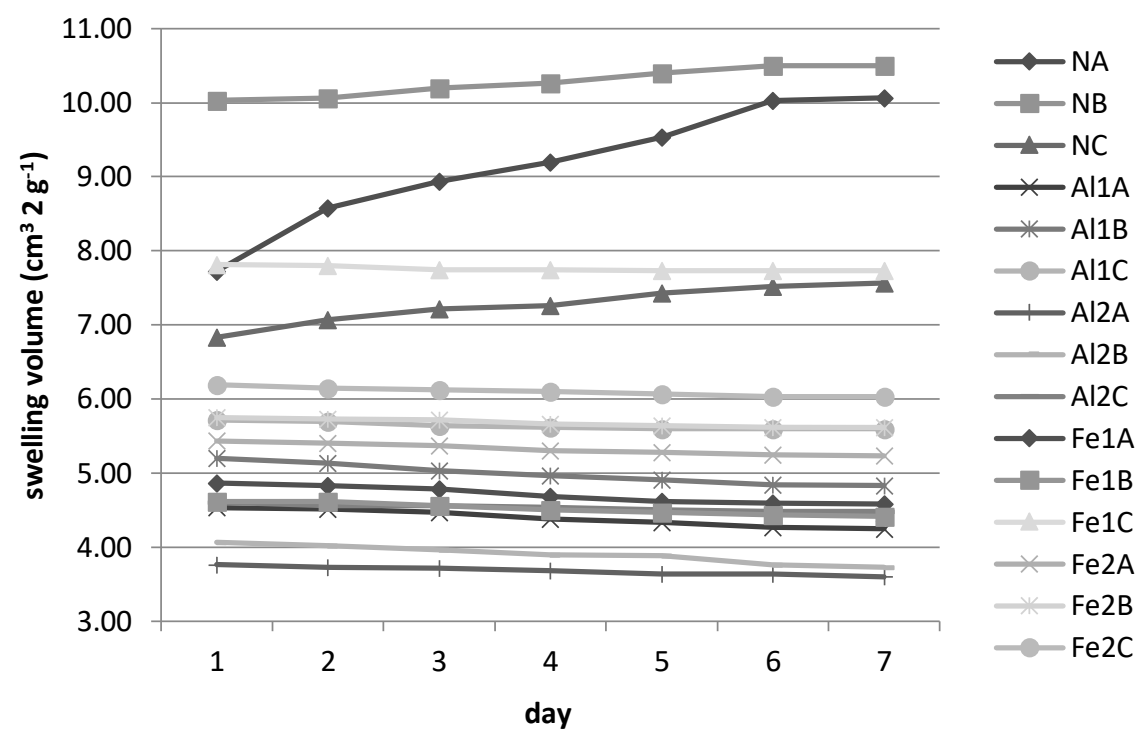

Figure 3. The average swelling volume of clay $(2 \mathrm{~g})$ in a water-saturated condition for 7 days

Table 13. ANOVA of average crack width after drying

\begin{tabular}{ccccc}
\hline Source & SS & MS & F & Sig. \\
\hline T & 0.027 & 0.027 & 38.529 & $* *$ \\
D & 5.841 & 2.920 & 4150.003 & $* *$ \\
C & 0.219 & 0.110 & 155.850 & $* *$ \\
$T^{*} \mathrm{D}$ & 0.016 & 0.008 & 11.292 & $* *$ \\
$\mathrm{~T}^{*} \mathrm{C}$ & 0.001 & 0.001 & 0.966 & $\mathrm{~ns}$ \\
$\mathrm{~T}^{*} \mathrm{D}^{*} \mathrm{C}$ & 0.531 & 0.066 & 94.268 & $* *$ \\
\hline
\end{tabular}

Remarks: $\mathrm{T}=$ type of intercalant; $\mathrm{D}=$ dose; $\mathrm{C}=$ calcination temperature; ${ }^{* *}=\mathrm{p}$-value $<0.01 ; \mathrm{ns}=$ not significant

Table 14. Average crack width after drying $(\mathrm{cm})$

\begin{tabular}{cccc}
\hline & \multicolumn{3}{c}{ Mean average crack width (cm) } \\
\cline { 2 - 4 } Type and & \multicolumn{3}{c}{ Calcination temperature } \\
\cline { 2 - 4 } intercalant dose & $\begin{array}{c}\text { Without } \\
\text { calcination } \\
\text { (A) }\end{array}$ & $200{ }^{\circ} \mathrm{C}(\mathrm{B})$ & $300^{\circ} \mathrm{C}(\mathrm{C})$ \\
\hline 0x CEC (N) & $0.935 \mathrm{~g}$ & $2.038 \mathrm{i}$ & $1.144 \mathrm{~h}$ \\
$\mathrm{Al} 0.5 \times \mathrm{CEC}$ (Al1) & $0.183 \mathrm{ab}$ & $0.174 \mathrm{ab}$ & $0.232 \mathrm{cde}$ \\
$\mathrm{Al} 1 \times$ CEC (Al2) & $0.156 \mathrm{a}$ & $0.158 \mathrm{a}$ & $0.189 \mathrm{ab}$ \\
Fe 0.5 CEC (Fe1) & $0.191 \mathrm{abc}$ & $0.205 \mathrm{bcd}$ & $0.344 \mathrm{f}$ \\
Fe 1x CEC (Fe2) & $0.232 \mathrm{cde}$ & $0.240 \mathrm{de}$ & $0.252 \mathrm{e}$ \\
\hline
\end{tabular}

Remark: Mean with the same letter in the same column is not significantly different at $\alpha=0.05$

The clay with intercalation by Al cations is better than that with intercalation by Fe cations; as Table 4 displays, the smallest swelling volume of clay was dominant in the clay with intercalation by $\mathrm{Al}$ cations. The transformation of intercalant cations ( $\mathrm{Al}$ or $\mathrm{Fe}$ ) into oxide pillars is probably related to the response of each intercalant cation to high temperature, that is, the melting point of each atom. Atomic Fe has a melting point up to $1.538{ }^{\circ} \mathrm{C}$ if heated up to $300{ }^{\circ} \mathrm{C}$ estimated that it has not been able to completely turn intercalant Fe to form oxide pillars, in contrast to intercalant Al which has turned into oxide pillars with calcination treatment of up to $300{ }^{\circ} \mathrm{C}$ because had a melting point only
$660.3{ }^{\circ} \mathrm{C}$. Therefore, the swelling volume of clay with Fe intercalation tends to be higher than that with Al intercalation (Figure 3). The Fe cation could not completely turn into pillar oxide, as shown in Table 16. The increased $\mathrm{pH}$ in the Fe intercalation is smaller than that in the $\mathrm{Al}$ intercalation when the calcination temperature was increased. The cation intercalant $\mathrm{Fe}$ probably requires a higher heating temperature and a longer time to completely change into pilar oxide form. However, it should also be considered that heating (calcination) at too high a temperature can cause structural damage to the clay (Irawati et al., 2013).

Table 4 shows that the clay with $\mathrm{Fe}$ intercalation treatment dominantly had a higher swelling volume than the clay with Al intercalation treatment. Intercalant Fe that has not yet turned into an oxide pillar can still experience a hydration effect or react with water molecules. The hydrated cation is larger in size (radius) (Teich-mcgoldrick et al., 2015), which weakens its cation bond with the charge of clay, so that chance pushed the interlayer space to be wider (swelling) (Xu et al., 2017). Table 6 also shows that the higher water content remaining in the clay after drying was found in the treatment with an Fe intercalation dose of $1 \times$ CEC; this is because the Fe cation intercalant was still reacting with water. The cations attached to the clay charge (interlayer space) also play a role in retaining the water content when the cations are in a hydrated condition (Sun et al., 2015).

\subsection{Total area and crack width of clay after drying}

Table 8 shows that the clay with an Al intercalation dose of $1 \times$ CEC without calcination had the highest total area after drying, followed by the clay with an Al intercalation dose of $1 \mathrm{x}$ CEC and calcination temperature of $200^{\circ} \mathrm{C}$. These measurement results show that with this treatment, clay has a low swelling ability; besides, clay had the smallest swelling volume (Table 4) and smallest average crack width after drying (Table 14). The swelling of clay produces a pressure force between the clay particles, causing a rearrangement of the clay particles (Pértile et al., 2016; Schanz \& Al-badran, 2014). 
(a)

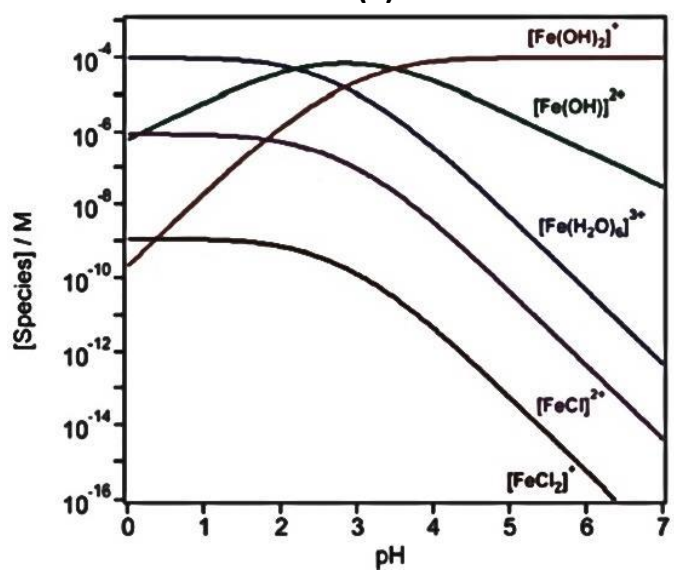

(b)

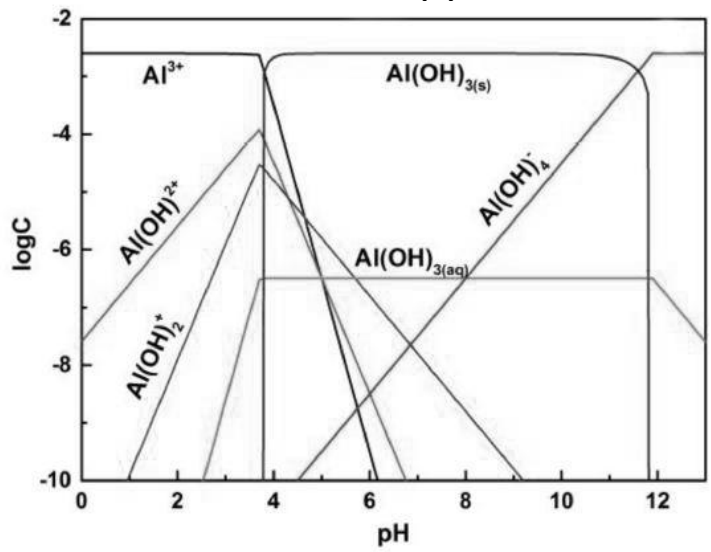

Figure 4. (a) Relationship between the form of Fe molecules/species and the $\mathrm{pH}$ of the solution (Al-Abadleh, 2015), and (b) relationship between the form of Al molecules/species and the $\mathrm{pH}$ of the solution (Ruan et al., 2018)

The swelling can occur in various directions depending on the position of the expansive clay sheet. The swelling of clay to a certain level tends to dominate the rearrangement of clay particles, stacked vertically upwards, because free space for the horizontal swelling of clay particles is the maximum (confined by the petri dish wall), and there is still free space for the clay particles to swell on the surface. The swollen clay forms cracks when it dries, which is due to the suction force between each particle (Lang et al., 2019; Tang et al., 2020); this suction force reduces the total area of the clay when viewed from above, and wider cracks are formed. Table 4 shows that the clay without intercalation (dose $0 x$ CEC) and calcination treatment of $200{ }^{\circ} \mathrm{C}$ had the highest swelling volume, the lowest total area after drying (Table 8), and the highest average crack width after drying (Table 14). The higher the ability of clay to absorb water, the higher its swelling ability, and the wider the crack forms when the clay dries (Painuli et al., 2017).

The clay with an Al intercalation dose of $1 \times$ CEC without calcination treatment had the highest total area because of the presence of polyvalent cations from the intercalation treatment and organic matter in the initial clay (Table 2). These polyvalent cations become the aggregation or binding agents in the soil, especially when they are associated with organic matter to form organo-minerals (Bedel et al., 2018). Polyvalent cations also cause soil particles to flocculate and increase soil particle aggregation (Rowley et al., 2018). The reduced total area after drying can be used as an indicator of the lower swelling-shrinking activity of clay, but this indicator cannot always be used as a definite reference. The results of the total area of the clay without intercalation (dose 0x CEC) and calcination treatment compared to clay with treatments, such as an Fe intercalation dose $0.5 \times$ CEC without calcination, an $\mathrm{Al}$ intercalation dose $1 \times \mathrm{CEC}$ and calcination $300{ }^{\circ} \mathrm{C}$, or an Fe intercalation dose $1 \times$ CEC without calcination, showed that the clay without intercalation (dose $0 x$ CEC) and calcination treatment had the highest total area after drying (Table 8); however, on this results test volume of swelling the clay without intercalation (Ox CEC) and without calcination treatment had the highest swelling volume (Table 4).

\subsection{Total number of lumps and average lump area after drying}

The clay with intercalation $0 x$ CEC without calcination treatment and intercalation $0 \times$ CEC and $200{ }^{\circ} \mathrm{C}$ calcination treatment had the smallest total number of lumps (Table 10); the total number of lumps is correlated with the suction force that occurs when the clay dries. As described previously, the suction force is the side effect of drying the swollen clay (Tang et al., 2011); the higher the swelling of clay, the higher the suction force when drying occurs. Clay in water-saturated conditions or a swollen condition experiences an adhesion force (clay-water molecules) and a cohesion force (waterwater molecules or clay-clay), but the adhesion force is more dominant than the cohesion force (Basmenj et al., 2016). The parts of the clay that have lost water molecules tend to be attracted toward the parts of clay that still have water molecules. The clay without intercalation (Ox CEC) without calcination or $200{ }^{\circ} \mathrm{C}$ calcination treatment first lost water molecules from the part in contact with the petri dish wall; this is because the holding force of water molecules on the parts between clay particles was stronger than the parts in contact with the petri dish wall. The initial organic matter (Table 2), which has not yet been lost in this treatment, would strengthen the holding force of the water molecules and decrease the rate of the losing water molecules, causing the edge of the clay to be pulled slowly toward the middle part of the clay lump (center of the petri dish), which still had water molecules (adhesion > cohesion). This is the reason why clay without intercalation ( $0 \times \mathrm{CEC}$ ) without calcination or clay with intercalation (Ox CEC) and $200{ }^{\circ} \mathrm{C}$ calcination treatment was consolidated into one large lump.

There was a slight correlation between the results of the clay-swelling volume test (Table 4) with the total number of lumps after drying (Table 10) and the average lump area after drying (Table 12). Clay without an intercalation dose (0x CEC) and without calcination or with calcination $\left(200^{\circ} \mathrm{C}\right.$ or $\left.300^{\circ} \mathrm{C}\right)$ had the highest swelling volume, the smallest total number of lumps after drying, and the highest average lump area after drying; this is related closely to the side effects that occur-

Table 15. ANOVA of $\mathrm{pH}$ of clay after treatment

\begin{tabular}{ccccc}
\hline Source & SS & MS & $\mathrm{F}$ & Sig. \\
\hline $\mathrm{T}$ & 2.894 & 2.894 & 558.036 & $* *$ \\
$\mathrm{D}$ & 3.974 & 1.987 & 383.250 & $* *$ \\
$\mathrm{C}$ & 1.444 & 0.722 & 139.286 & $* *$ \\
$\mathrm{~T}^{*} \mathrm{D}$ & 1.827 & 0.914 & 176.179 & $* *$ \\
$\mathrm{~T}^{*} \mathrm{C}$ & 0.041 & 0.021 & 4.000 & $*$ \\
$\mathrm{~T}^{*} \mathrm{D}^{*} \mathrm{C}$ & 1.621 & 0.203 & 39.071 & $* *$ \\
\hline
\end{tabular}

Remarks: $\mathrm{T}=$ type of intercalant; $\mathrm{D}=$ dose; $\mathrm{C}=$ calcination temperature; ${ }^{*}=p$-value $<0.05 ;{ }^{* *}=p$-value $<0.01$ 
Table 16. $\mathrm{pH}$ of clay after treatment

\begin{tabular}{cccc}
\hline \multirow{2}{*}{ Type and } & \multicolumn{3}{c}{ Mean pH of clay } \\
\cline { 2 - 4 } intercalant dose & \multicolumn{3}{c}{ Calcination temperature } \\
\cline { 2 - 4 } & $\begin{array}{c}\text { Without } \\
\text { calcination (A) }\end{array}$ & $200{ }^{\circ} \mathrm{C}$ & $300{ }^{\circ} \mathrm{C}$ \\
\hline 0x CEC (N) & $4.77 \mathrm{bc}$ & $4.73 \mathrm{c}$ & $4.67 \mathrm{~cd}$ \\
Al 0.5x CEC (Al1) & $3.93 \mathrm{~g}$ & $4.27 \mathrm{f}$ & $4.93 \mathrm{a}$ \\
Al 1x CEC (Al2) & $4.40 \mathrm{e}$ & $4.57 \mathrm{~d}$ & $4.87 \mathrm{ab}$ \\
Fe 0.5 CEC (Fe1) & $3.57 \mathrm{i}$ & $3.73 \mathrm{~h}$ & $4.37 \mathrm{ef}$ \\
Fe 1x CEC (Fe2) & $3.60 \mathrm{i}$ & $3.67 \mathrm{hi}$ & $3.87 \mathrm{~g}$ \\
\hline
\end{tabular}

Remark: Mean with the same letter in the same column is not significantly different at $\alpha=0.05$

when the clay swells (pressure force) and dries (suction force) (Lang et al., 2019). The pressure force effect occurs when the clay swells, and the suction force effect occurs when the clay dries (Bamgbopa, 2016). The larger the number of water molecules that fill the interlayer space (swelling process), the greater the suction force effect caused when the clay dries. The fewer number of clay lumps formed indicate that the suction force effect was greater on clay when it dried. In addition, the rate of water loss affects the total number and area of the lump after drying.

When the clay starts drying, clay particles are pulled close to each other by water molecules using hydrogen bonds, like a connecting bridge between clay particles. Polyvalent cations also play a role similar to that of water molecules in attracted clay particles (Seppälä et al., 2016). Polyvalent cations actively use their negative charge to bridge the clay layer to another clay layer, so that they are kept close to each other (Zhao et al., 2012); this is why smaller lumps are formed in clay samples given intercalant cation treatment. The greater water content in clay (up to twice the plastic limit) makes the adhesion force greater and the cohesion force less (Basmenj et al., 2016). The presence of polyvalent cations limits the total number of water molecules that could enter the interlayer space, so the water content that could be absorbed by clay is low, and the swelling that occurs in the clay is smaller. The rate of water loss also affects the average lump area formed. The slower the rate of water loss, the longer the clay has an adhesion (attraction) force that keeps the clay particles close together during the shrinkage process, which makes the lump area higher. This explains why clay with an $\mathrm{Al}$ intercalation dose of $1 \times \mathrm{CEC}$ and $300^{\circ} \mathrm{C}$ calcination treatment has the lowest average lump area (Table 12) and showed a relatively low swelling volume (Table 4). The clay samples with $\mathrm{Al}$ intercalation doses of $1 \times$ CEC and $0.5 \times$ CEC, both without calcination treatments, had lower test swelling volumes, but their average lump areas were not lower than clay with an Al intercalation dose of $1 \mathrm{x} \mathrm{CEC}$ and $300{ }^{\circ} \mathrm{C}$ calcination; this is because the intercalation cations are still in form could be bonded with water and affect the lower water loss rate.

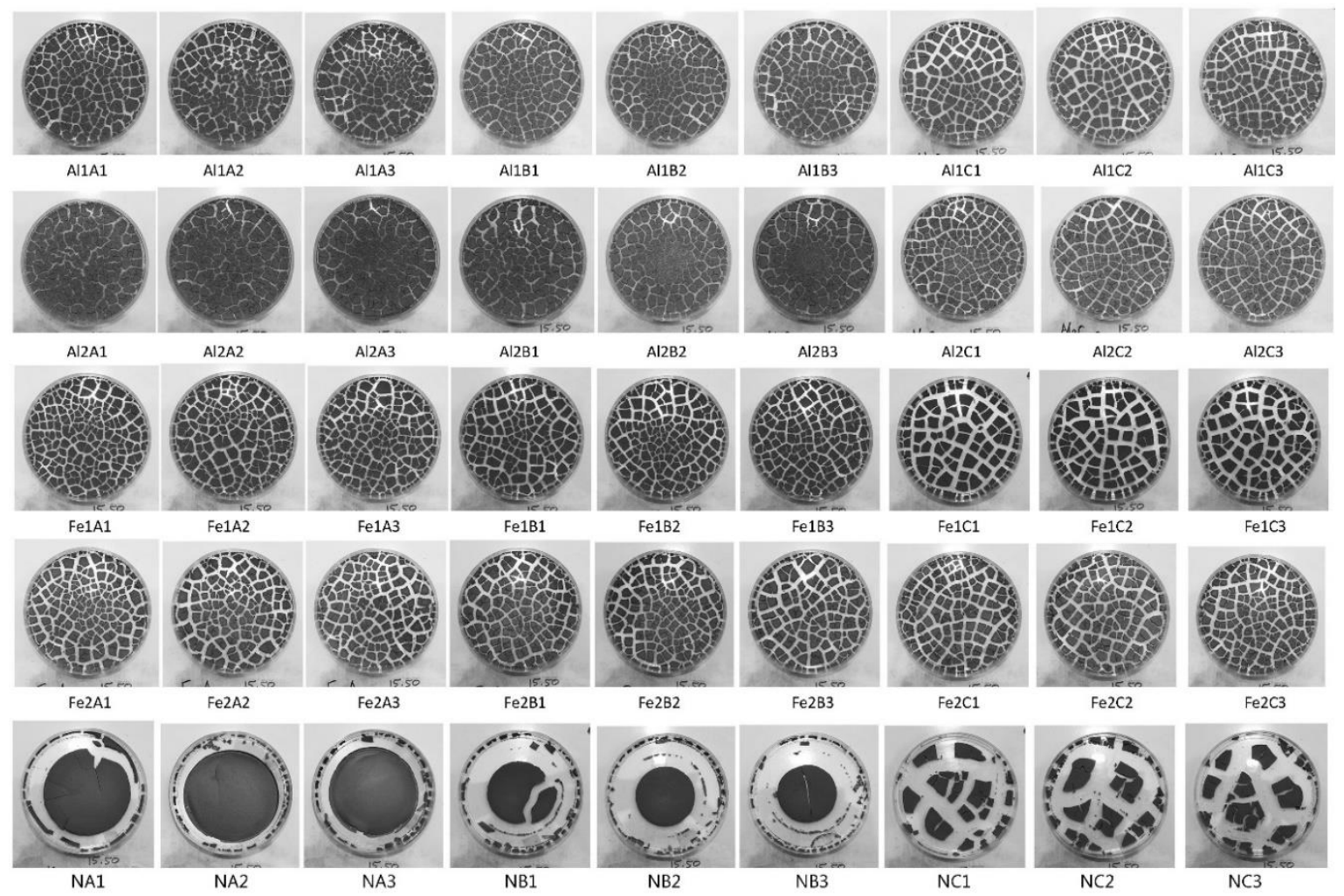

Figure 5. Results of drying treated clay for 7 days in a Petri dish

Notes: $\mathrm{Al} 1$ = intercalation with aluminum (Al) dose $0.5 x$ CEC; Al2 = intercalation with Al dose $1 \times$ CEC; Fe1 = intercalation with iron (Fe) dose $0.5 x$ CEC; Fe2 = intercalation with Fe dose 1x CEC; $A 1$ = without calcination repetition $1 ; A 2=$ without calcination repetition $2 ; \mathrm{A} 3=$ without calcination repetition $3 ; \mathrm{B} 1=$ calcination $200^{\circ} \mathrm{C}$ repetition $1 ; \mathrm{B} 2=$ calcination $200^{\circ} \mathrm{C}$ repetition $2 ; \mathrm{B} 3=$ calcination $200^{\circ} \mathrm{C}$ repetition $3 ; \mathrm{C} 1=$ calcination $300^{\circ} \mathrm{C}$ repetition $1 ; \mathrm{C} 2=$ calcination $300^{\circ} \mathrm{C}$ repetition $2 ; \mathrm{C} 3=$ calcination $300^{\circ} \mathrm{C}$ repetition 3 
The crack width in the clay without intercalation (0x CEC) without calcination treatment could not be calculated properly (Table 14). The measurement was calculated based on the average distance between the edge of the clay lump and the petri dish wall, not the distance between two lumps; this was because only a few lumps were formed with this treatment. The clay without intercalation (Ox CEC) without calcination treatment also did not show any cracks (Figure 5), because the test area was only limited to the petri dish. If the drying medium (petri dish) is used on the wider area, the crack width that occurs on that treated clay would be more clearly visible.

\section{4. $\mathrm{pH}$ of clay after treatment}

The $\mathrm{pH}$ test of clay samples was conducted to assess the successful formation of oxide pillars in clay interlayer spaces, which could be a reference of the possibly dangerous environmental toxicity effect if intercalation and calcination methods are used directly in soil. Table 16 shows that the clay without an intercalation dose (0x CEC) without calcination, or $200{ }^{\circ} \mathrm{C}$ or $300{ }^{\circ} \mathrm{C}$ calcination treatment produced a pattern of decreasing $\mathrm{pH}$ along with the increasing calcination temperature; this was because the heat treatment caused the breakdown of the main elements of organic matter, such as $\mathrm{H}^{-}$. Table 16 shows that clay that received intercalation treatment experienced a pattern of increasing $\mathrm{pH}$ along with the increasing calcination treatment. When intercalant molecules enter the interlayer space, dehydration and dehydroxylation reactions occur, and intercalant molecules interact with each other to form $\mathrm{Fe}_{2} \mathrm{O}_{3}$ or $\mathrm{Al}_{2} \mathrm{O}_{3}$ and then form strong oxide bonds with the charges on the clay (Nugrahaningtyas et al., 2016). This dehydration and dehydroxylation process results in the release of $\mathrm{OH}^{-}$ molecules, which increases the $\mathrm{pH}$ of clay. Intercalation treatment with an $\mathrm{Al}$ intercalant results in a higher $\mathrm{pH}$ than with an Fe intercalant; this was because of the made process of Fe intercalant solution on lower $\mathrm{pH}$ conditions than $\mathrm{Al}$ intercalant solution. The successful formation of the oxide pillar structure also affects the $\mathrm{pH}$ value. The more successfully the oxide pillar is formed, the greater the number of $\mathrm{OH}^{-}$molecules released, increasing the $\mathrm{pH}$ of clay. The success rate of pillar formation with an Al intercalant is estimated to be higher than that with an Fe intercalant, as proved in Table 16; the graph pattern of increasing $\mathrm{pH}$ is sharper with the $\mathrm{Al}$ intercalant treatment when the calcination temperature is increased. The combination of the type of intercalant cation and the calcination temperature is very important as it determines the success and effectiveness of the formation of the oxide pillar structure in the clay interlayer space.

\section{Conclusions}

The intercalation and calcination method could reduce the expansive ability of clay by approximately $50 \%$. Based on our experimental results, an Al intercalation dose of 1x CEC and calcination temperature of $200{ }^{\circ} \mathrm{C}$ were the best treatment to reduce the expansive and swelling ability of clay, and to reduce the crack width of clay after drying, compared with the other treatments. The clay with an Al intercalation dose of $1 x$ CEC without calcination treatment also had a relatively low swelling-shrinking ability test result, but this treatment had the potential to form cracks wider than in the treatment with calcination. The $\mathrm{Al}$ intercalation dose of $1 \mathrm{x}$ CEC and $200{ }^{\circ} \mathrm{C}$ calcination treatment could be used as a guideline for further testing to reduce the potential swellingshrinking properties in soil.

\section{Declaration of Competing Interest}

The authors declare no competing financial or personal interests that may appear and influence the work reported in this paper.

\section{Acknowledgements}

This study was supported by the UGM-RTA project program which funded international publication no. 3143/UN1.P.III/DIT-LIT/PT/2021.

\section{References}

Aksu, I., Bazilevskaya, E., \& Karpyn, Z. T. (2015). Swelling of clay minerals in unconsolidated porous media and its impact on permeability. GeoResJ, 7, 1-13. https://doi.org/10.1016/j.grj.2015.02.003

Alazigha, D. P., Indraratna, B., Vinod, J. S., \& Ezeajugh, L. E. (2016). The swelling behaviour of lignosulfonatetreated expansive soil. Proceedings of the Institution of Civil Engineers: Ground Improvement, 169, 182-193. https://doi.org/10.1680/jgrim.15.00002

Bamgbopa, O. S. (2016). Investigation of shrinkage and cracking in clay soils under wetting and drying cycles. International Journal of Engineering Research \& Technology (IJERT), 5(11), 283-320. https://doi.org/10.17577/ijertv5is110183

Basmenj, A. K., Mirjavan, A., Ghafoori, M., \& Cheshomi, A. (2016). Assessment of the Adhesion Potential of Kaolinite and Montmorillonite using a Pull-Out Test Device. Bulletin of Engineering Geology and the Environment, 76, 1507-1519. https://doi.org/10.1007/s10064-016-0921-3

Bedel, L., Legout, A., Poszwa, A., van der Heijden, G., Court, M., Goutal-Pousse, N., Montarges-Pelletier, E., \& Ranger, J. (2018). Soil aggregation may be a relevant indicator of nutrient cation availability. Annals of Forest Science, 75, 1-12. https://doi.org/10.1007/s13595-018-0782-y

Chang, P. H., Jiang, W. T., \& Li, Z. (2019). Removal of perfluorooctanoic acid from water using calcined hydrotalcite - A mechanistic study. Journal of Hazardous Materials, 368, 487-495. https://doi.org/10.1016/j.jhazmat.2019.01.084

Cheng, Y., \& Huang, X. (2019). Effect of mineral additives on the behavior of an expansive soil for use in highway subgrade soils. Applied Sciences (Switzerland), 9, 1-14. https://doi.org/10.3390/app9010030

DeCarlo, K. F., \& Caylor, K. K. (2020). Effects of crack morphology on soil carbon flux dynamics in a dryland vertisol. Geoderma, 375, 1-14. https://doi.org/10.1016/j.geoderma.2020.114478 
Hidalgo, C., Merino, A., Osorio-hernández, V., Etchevers, J. D., Figueroa, B., Limon, A., \& Aguirre, E. (2019). Physical and chemical processes determining soil organic matter dynamics in a managed vertisol in a tropical dryland area. Soil \& Tillage Research, 194, 1-9. https://doi.org/10.1016/j.still.2019.104348

Irawati, U., Sunardi, \& Suraida. (2013). Sintesis dan Karakterisasi Alumina ( $\gamma$-Al2O3) Dari Kaolin Asal Tatakan, Kalimantan Selatan Berdasarkan Variasi Temperatur Kalsinasi. Molekul, 8, 31-42. https://doi.org/10.20884/1.jm.2013.8.1.123

Khadka, S. D., Jayawickrama, P. W., Senadheera, S., \& Segvic, B. (2020). Stabilization of highly expansive soils containing sulfate using metakaolin and $\mathrm{fl}$ y ash based geopolymer modi $\mathrm{fi}$ ed with lime and gypsum. Transportation Geotechnics, 23, 1-13. https://doi.org/10.1016/j.trgeo.2020.100327

Lang, L. Z., Tripathy, S., Baille, W., Schanz, T., \& Sridharan, A. (2019). Linkage between swelling pressure, total suction of saturated bentonites and suction of saturating aqueous solutions. Applied Clay Science, 171 ,

https://doi.org/10.1016/j.clay.2019.02.007

Lee, S. G., Ha, J.-w., Sohn, E.-h., Park, I. J., \& Lee, S.-b. (2017). Synthesis of pillar and microsphere-like magnesium oxide particles and their fluoride adsorption performance in aqueous solutions. Korean Journal of Chemical Engineering, 34, 1-10. https://doi.org/10.1007/s11814-017-0160-8

Li, J. H., \& Zhang, L. M. (2011). Study of desiccation crack initiation and development at ground surface. Engineering Geology, 123, 347-358. https://doi.org/10.1016/j.enggeo.2011.09.015

Michette, M., Lorenz, R., \& Ziegert, C. (2017). Clay barriers for protecting historic buildings from ground moisture intrusion. Heritage Science, 5, 1-11. https://doi.org/10.1186/s40494-017-0144-3

Mirzababaei, M., Arulrajah, A., \& Ouston, M. (2017). Polymers for Stabilization of Soft Clay Soils. Procedia Engineering, 189, 25-32. https://doi.org/10.1016/j.proeng.2017.05.005

Mnasri-Ghnimi, S., \& Frini-Srasra, N. (2019). Removal of heavy metals from aqueous solutions by adsorption using single and mixed pillared clays. Applied Clay Science, 179, 1-17. https://doi.org/10.1016/j.clay.2019.105151

Nugrahaningtyas, K. D., Widjonarko, D. M., Daryani, \& Haryanti, Y. (2016). Kajian Aktivasi H2SO4 terhadap Proses Pemilaran Al2O3 Pada Lempung Alam. ALCHEMY Jurnal Penelitian Kimia, 12, 190-203. https://doi.org/10.20961/alchemy.v12i2.1312

Painuli, D. K., Mohanty, M., Sinha, N. K., \& Misra, A. K. (2017). Crack Formation in a Swell-Shrink Soil Under Various Managements. Agricultural Research, 6, 66-72. https://doi.org/10.1007/s40003-016-0241-7

Pértile, P., Reichert, J. M., Gubiani, P. I., Holthusen, D., \& Costa, A. d. (2016). Rheological Parameters as Affected by Water Tension in Subtropical Soils. Sociedade
Brasileira de Ciência do Solo, 40, 1-14. https://doi.org/10.1590/18069657rbcs20150286

Rajoria, V., \& Kaur, S. (2014). A Review on Stabilization of Soil using Various Admixtures. International Journal of Engineering Research and, 3, 75-78. https://doi.org/10.17577/IJERTV6IS020332

Rowley, M. C., Grand, S., \& Verrecchia, É. P. (2018). Calciummediated stabilisation of soil organic carbon. Biogeochemistry, 137, 27-49. https://doi.org/10.1007/s10533-017-0410-1

Schanz, T., \& Al-badran, Y. (2014). Swelling pressure characteristics of compacted Chinese Gaomiaozi. Soils and Foundations, 54, 748-759. https://doi.org/10.1016/j.sandf.2014.06.026

Seppälä, A., Puhakka, E., \& Olin, M. (2016). Effect of layer charge on the crystalline swelling of $\mathrm{Na}+, \mathrm{K}+$ and $\mathrm{Ca}$ 2+ montmorillonites: DFT and molecular dynamics studies Clay Minerals, 51, 197-211. https://doi.org/10.1180/claymin.2016.051.2.07

Sholeh, M. (2012). Pengaruh Proses Pembasahan dan Pengeringan pada Tanah Ekspansif yang Distabilisasi dengan Kapur dan Eco Cure21 (Studi Kasus: Jalan Bojonegoro-Padangan Km $133+550)$. JURNAL TEKNIK SIPIL, 6, 143-155. https://doi.org/10.33795/prokons.v6i2.23

Sun, L., Tanskanen, J. T., Hirvi, J. T., Kasa, S., Schatz, T., \& Pakkanen, T. A. (2015). Molecular dynamics study of montmorillonite crystalline swelling : Roles of interlayer cation species and water content. CHEMICAL PHYSICS, 455, 23-31. https://doi.org/10.1016/j.chemphys.2015.04.005

Tang, C.-S., Cheng, Q., Leng, T., Shi, B., Zeng, H., \& Inyang, H. I. (2020). Effects of wetting-drying cycles and desiccation cracks on mechanical behavior of an unsaturated soil. Catena, 194, 1-11. https://doi.org/10.1016/j.catena.2020.104721

Tang, C.-S., Shi, B., Liu, C., Suo, W.-b., \& Gao, L. (2011). Applied Clay Science Experimental characterization of shrinkage and desiccation cracking in thin clay layer. Applied Clay Science, 52, 69-77. https://doi.org/10.1016/j.clay.2011.01.032

Teich-mcgoldrick, S. L., Greathouse, J. A., Jové-Colón, C. F., \& Cygan, R. T. (2015). Swelling Properties of Montmorillonite and Beidellite Clay Minerals from Molecular Simulation: Comparison of Temperature, Interlayer Cation, and Charge Location Effects. The Journal of Physical Chemistry, 119, 20880-20891. https://doi.org/10.1021/acs.jpcc.5b03253

Wan, Q., Rao, F., \& Song, S. (2017). Reexamining calcination of kaolinite for the synthesis of metakaolin geopolymers - roles of dehydroxylation and recrystallization. Journal of Non-Crystalline Solids, 460, 74-80. https://doi.org/10.1016/j.jnoncrysol.2017.01.024

Xu, J., Camara, M., Liu, J., Peng, L., Zhang, R., \& Ding, T. (2017). Molecular dynamics study of the swelling patterns of $\mathrm{Na} / \mathrm{Cs}-$, Na / Mg-montmorillonites and hydration of 
interlayer cations. Molecular Simulation, 43, 1-15. https://doi.org/10.1080/08927022.2016.1274982

Yuliet, R., Hakam, A., \& Febrian, G. (2011). Uji potensi mengembang pada tanah lempung dengan metoda. Jurnal Rekayasa Sipil, 7, 25-36. https://doi.org/DOI: 10.25077/jrs.7.1.25-36.2011

Zhao, H., Ge, L., Petry, T. M., \& Sun, Y. Z. (2014). Effects of chemical stabilizers on an expansive clay. KSCE Journal of Civil Engineering, 18, 1009-1017. https://doi.org/10.1007/s12205-013-1014-5

Zhao, Y., Gu, X., Gao, S., Geng, J., \& Wang, X. (2012). Adsorption of tetracycline ( TC ) onto montmorillonite : Cations and humic acid effects. Geoderma, 183-184, 12-18.

https://doi.org/10.1016/j.geoderma.2012.03.004 